\title{
A novel 65 kDa RNA-binding protein in squid presynaptic terminals
}

D. T. P. Lico ${ }^{1}$, J. C. Rosa ${ }^{1}$, J. A. DeGiorgis ${ }^{2,4,5}$, E. J. R. deVasconcelos ${ }^{1}$, L. Casaletti ${ }^{1 *}$, S. B. F.

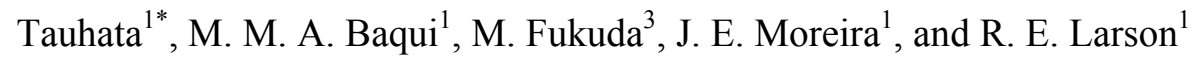

${ }^{1}$ Dept. Cellular \& Molecular Biology, Faculdade de Medicina de Ribeirão Preto, Universidade de São Paulo, Ribeirão Preto, São Paulo, Brazil 14049-900; ${ }^{2}$ Marine Biological Laboratory, Woods Hole, MA. 02543; ${ }^{3}$ Dept. Developmental Biology \& Neurosciences, Graduate School of Life Sciences, Tohoku University, Miyagi 980-8578 Japan; ${ }^{4}$ Biology Dept. Providence College, Providence, RI 02918; ${ }^{5}$ National Institute of Neurological Disorders and Stroke, NIH, Bethesda, MD 20892.

* Present address:

Dept. Biological Sciences

063 Galvin Life Science Center

University of Notre Dame, Notre Dame IN 46556.

\section{Corresponding author:}

R.E. Larson

Tel 55-16-3602-3319; Fax: 55-16-3633-1786

e-mail: relarson@ffmrp.usp.br

Running title: Novel RNA-binding protein in presynaptic terminals 
Abbreviations: CID-MS/MS, collision-induced dissociation mass spectrometry; DEPC, diethyl pyrocarbonate; DTT, dithiothreitol; EDTA, ethylenediaminetetra-acetate; EPI-MS/MS, electrospray ion mass spectrometry; EST, expressed sequence tags; FPLC, fast protein liquid chromatography; hnRNP, heterogeneous nuclear ribonucleoprotein; MALDI-TOF/TOF-MS, matrix assisted laser desorption, time-of-flight mass spectrometry; PAGE, polyacrylamide gel electrophoresis; PVDF, polyvinyldifluoride; PMSF, phenylmethylsulfonyl fluoride; PBS, phosphate buffered saline; SDS, sodium dodecyl sulfate 
Abstract A polyclonal antibody (C4), raised against the head domain of chicken myosin Va, reacted strongly towards a $65 \mathrm{kDa}$ polypeptide (p65) on western blots of extracts from squid optic lobes but did not recognize the heavy chain of squid myosin V. This peptide was not recognized by other myosin $\mathrm{Va}$ antibodies, nor by an antibody specific for squid myosin $\mathrm{V}$. In an attempt to identify it, p65 was purified from optic lobes of Loligo plei by cationic exchange and reverse phase chromatography. Several peptide sequences were obtained by mass spectroscopy from p65 cut from SDS-PAGE gels. BLAST analysis and partial matching with ESTs from a Loligo pealei data bank indicated that p65 contains consensus signatures for the hnRNP A/B family of RNA-binding proteins. Centrifugation of post mitochondrial extracts from optic lobes on sucrose gradients after treatment with RNase gave biochemical evidence that p65 associates with cytoplasmic RNP complexes in an RNA-dependent manner. Immunohistochemistry and immunofluorescence studies using the $\mathrm{C} 4$ antibody showed partial co-labeling with an antibody against squid synaptotagmin in bands within the outer plexiform layer of the optic lobes and at the presynaptic zone of the stellate ganglion. Also, punctate labeling by the $\mathrm{C} 4$ antibody was observed within isolated optic lobe synaptosomes. The data indicate that p65 is a novel RNA-binding protein located to the presynaptic terminal within squid neurons and may have a role in synaptic localization of RNA and its translation or processing.

Key words: myosin V; hnRNP complex; RNP motifs; synaptosome; optic lobe; Loligo

Regulated RNA translation systems are found in axons and presynaptic terminals as well as in dendrites and postsynaptic terminals of neurons where they control protein synthesis in response to specific needs of these subcellular domains (Giuditta et al., 2002;Schuman et al., 2006;Steward and Schuman, 2003;Pfeiffer and Huber, 2006;Sotelo-Silveira et al., 2006; Twiss and Fainzilber, 2009). Experiments on the squid giant synapses in the stellate ganglion and the large synaptosomes prepared from the photoreceptor neurons of squid optic lobes have demonstrated that the presynaptic terminal is endowed with an active system of protein synthesis (Crispino et al., 
1997; Crispino et al., 1993; Gioio et al., 2004;Jimenez et al., 2002;Kaplan et al., 2004). There is evidence to support the idea that a subset of neuronal mRNAs are selectively transported to and translated within the axon and the presynaptic terminal of these neurons (Crispino et al., 1997; Gioio et al., 2004;Kaplan et al., 2004). However, protein components and functions for regulated protein synthesis at the presynaptic terminal are not well characterized and need to be explored. Myosin V, an actin-based molecular motor ubiquitously found in eukaryotes, has been isolated and partially characterized from squid optic lobes and giant axons (Molyneaux et al., 2000;Cohen, 2001;Brown et al., 2004;Tabb et al., 1998). Myosin Vs represent one of the most well characterized classes of unconventional myosins (Langford, 2002;Trybus, 2008;Desnos et al., 2007). In vertebrate neuronal tissues, the paralog myosin $\mathrm{Va}(\mathrm{MVa})$ is localized at both pre- and postsynaptic sites and has been implicated in synaptic function and plasticity (Mani et al., 1994;Prekeris and Terrian, 1997; Walikonis et al., 2000; Takamori et al., 2006; Yoshimura et al., 2006; Correia et al., 2008). MVa and its mRNA have been identified in periaxoplasmic ribosomal plaques in axons (Calliari et al., 2002;Sotelo-Silveira et al., 2004) and, perhaps most remarkably, members of the myosin V class have been implicated in the transport and cytoplasmic localization of mRNA (Jansen et al., 1996; Yoshimura et al., 2006; Chang et al., 2008;Salerno et al., 2008). The exact function of MVa at the synapse has yet to be clarified. For this reason we investigated the possibility of using MVa antibodies as probes into the squid giant synapse, which is a model system for synaptic events. Serendipitously, we identified a novel $65 \mathrm{k}$, RNA- binding protein in the presynaptic terminals of squid nervous system.

\section{Experimental procedures}

\section{Tissue preparation from squid}

The optic lobes and stellate ganglia were dissected from freshly killed Loligo pealei obtained from the Marine Biological Laboratory in Woods Hole or from Loligo plei obtained from the Centro de Biologia Marinha-CEBIMar, University of São Paulo, São Sebastião, Brazil. 
Synaptosomes were prepared according to Crispino (Crispino et al., 1997) from four optic lobes

quickly dissected from decapitated squids and homogenized in $3 \mathrm{ml}$ of ice-cold homogenizing medium, $\mathrm{HM}(0.7 \mathrm{M}$ sucrose in $20 \mathrm{mM}$ Tris- $\mathrm{HCl}, \mathrm{pH}$ 7.4) in a loose-fitting, motor-driven, Teflonglass homogenizer by 8 slow up and down strokes. The homogenate was spun at 3,000 x g for 11 $\min$ at $4^{\circ} \mathrm{C}$ and the supernatant spun at $15,000 \times \mathrm{g}$ for $30 \mathrm{~min}$. The floating layer containing the synaptosomes was collected, resuspended in HM buffer and spun at 15,000 x g for $20 \mathrm{~min}$. The floating layer was again collected and resuspended in artificial seawater. For immunofluorescence studies both freshly prepared synaptosomes and dissected stellate ganglia were fixed in PLP buffer (phosphate buffered saline, $\mathrm{pH} 7.4$, containing $10 \mathrm{mM}$ sodium periodate, $75 \mathrm{mM}$ lysine and $0.5 \%$ paraformaldehyde for $6-8 \mathrm{hrs}$ at $4^{\circ} \mathrm{C}$. Samples were subsequently washed 3 times for $10 \mathrm{~min}$ in phosphate buffered saline (PBS) at $4{ }^{\circ} \mathrm{C}$ and treated as described below.

For purification and biochemical studies freshly dissected optic lobes were frozen in liquid nitrogen and stored at $-70^{\circ} \mathrm{C}$ until used.

\section{Antibodies}

Polyclonal antibodies to the head domain (C4 and C5) and medial tail domain ( $\alpha-M V a M T)$ of chicken myosin $\mathrm{Va}$ were raised in rabbits by inoculation with recombinant proteins, corresponding to aa 5-752 and aa 1117-1435, respectively (Espreafico et al., 1992;Costa et al., 1999). These antibodies were affinity purified on tissue-purified myosin Va (Cheney, 1998), immobilized on PVDF membranes. A polyclonal antibody against the $\mathrm{C} 2 \mathrm{~A}$ domain of squid synaptotagmin conjugated with rhodamine (anti-syt-C2A) was used to label synaptic vesicles (Fukuda et al., 1995;Mikoshiba et al., 1995). Secondary antibodies conjugated to alkaline phosphatase or peroxidase were obtained from Pierce (Rockford, IL) and to Alexa 488 from Molecular Probes (Invitrogen, Carlsbad, CA).

Purification by cationic and reverse phase chromatography 
Approximately $4 \mathrm{~g}$ (40 lobes) of frozen optic lobes were homogenized in $60 \mathrm{ml}$ of an $8 \mathrm{M}$ urea solution in buffer A (40 mM Hepes, pH 7.6, 10 mM EDTA, 3 mM DTT and protease inhibitors 1 $\mathrm{mM}$ benzamidine, $2 \mu \mathrm{g} / \mathrm{ml}$ aprotinin and $0.3 \mathrm{mM}$ PMSF) and centrifuged at 40,000 $\mathrm{x} \mathrm{g}$ for $40 \mathrm{~min}$ at $4^{\circ} \mathrm{C}$. The supernatant (S1) was diluted 1:1 volume in buffer A, without urea and centrifuged at $20,000 \mathrm{x} \mathrm{g}$ for $15 \mathrm{~min}$ at $4^{\circ} \mathrm{C}$. The supernatant (S2) was applied to a $15 \mathrm{ml} \mathrm{SP}-$ Sepharose column (GE Health Science, Chalfont St. Giles, UK) equilibrated in buffer A and eluted by application of a linear gradient from 0 to $1.2 \mathrm{M} \mathrm{NaCl}$ in buffer A. Fractions containing p65 identified by western blot were eluted at $750-900 \mathrm{mM} \mathrm{NaCl}$ and pooled. The pooled sample was fractionated by FPLC (ÄKTA purifier, GE Health Science) on a Source 5RPC SR 4.6/150 column (GE Health Science) using a non-linear gradient of 0 to $80 \%$ acetonitrile in $0.1 \%$ trifluoroacetic acid. Peak fractions were concentrated on a SpeedVac 5301 (Eppendorf, Hamburg, Germany) for further analysis.

\section{Immunoprecipitation}

Four optic lobes were homogenized in $6 \mathrm{ml}$ of $50 \mathrm{mM}$ Tris buffer, $\mathrm{pH} 7.5$ containing $5 \mathrm{mM}$ EDTA, $2 \mathrm{mM}$ DTT and protease inhibitors, $1 \mathrm{mM}$ benzamidine, $2 \mu \mathrm{g} / \mathrm{ml}$ aprotinin and $0.3 \mathrm{mM}$ PMSF, and centrifuged at $40,000 \mathrm{x}$ g for $20 \mathrm{~min}$. SDS to $0.3 \%$ was added to the supernatant and then heated to $60^{\circ} \mathrm{C}$ for $15 \mathrm{~min}$. Two $\mathrm{ml}$ aliquots of the supernatant were incubated with $50 \mu \mathrm{L}$ of Pansorbin cells (Calbiochem, Darmstadt, Germany) for $30 \mathrm{~min}$ at room temperature under gentle agitation. The material was centrifuged at 2,000 x g for $2 \mathrm{~min}$ and the pellet discarded. The sample was then incubated with $44 \mu \mathrm{g}$ of $\mathrm{C} 4$ antibody or $\alpha$-MVaMT for $2 \mathrm{~h}$ at room temperature and then re-incubated with $50 \mu \mathrm{L}$ of Pansorbin cells for $30 \mathrm{~min}$. After centrifugation for $2 \mathrm{~min}$, the pellet was washed 3 times with Tris-buffered saline and extracted in $50 \mu \mathrm{L}$ of SDS-PAGE sample buffer.

\section{In situ trypsin digestion and mass spectrometry}

The appropriate polypeptide band corresponding to p65 stained with colloidal Coomassie Blue (Imperial Protein Stain, Pierce) was excised from an 8\% polyacrylamide gel $(13 \times 13 \times 0.15 \mathrm{~cm})$ 
after SDS-PAGE. The protein band was washed 3 times with $50 \%$ acetonitrile in $0.1 \mathrm{M}$ ammonium bicarbonate, dehydrated with acetonitrile and dried under vacuum. The protein band was rehydrated with $0.5 \mu \mathrm{g}$ of trypsin in $20 \mu \mathrm{L}$ of $0.1 \mathrm{M}$ ammonium bicarbonate and submitted to in situ hydrolysis for $24 \mathrm{~h}$ at $37{ }^{\circ} \mathrm{C}$. Hydrolysis was stopped by addition of $5 \mathrm{uL}$ of formic acid and the tryptic peptides were desalted in a microtip filled with POROS R2 resin (Perseptive Biosystem, Foster City, CA) previously activated in methanol and equilibrated with $0.2 \%$ formic acid, then washed 3 times with $150 \mu \mathrm{L}$ of $0.2 \%$ formic acid. Peptides were eluted in $30 \mu \mathrm{L}$ of $5 \%$ formic acid in $60 \%$ methanol. Mass spectrometry analysis of the tryptic peptides was carried out in an electrospray triplequadrupole mass spectrometer Quattro II (Micromass, Manchester, UK) and MALDI-TOF-TOF Axima Performance (Kratos-Shimadzu Biotech, Manchester, UK). The sample was directly applied to electrospray ion source (ESI-3Q-MS) at $300 \mathrm{~nL} / \mathrm{min}$ under the following conditions: capillary voltage maintained at $2.8 \mathrm{kV}$, cone voltage at $40 \mathrm{~V}$ and cone temperature set to $100{ }^{\circ} \mathrm{C}$. In the mode of daughter ion scanning, the collision energy varied from 25 to $40 \mathrm{eV}$, and argon, at a partial pressure of $3.0 \times 10^{-3}$ mTorr, was used as a collision gas. Each spectrum is an average of 20-50 scans (2 to $5 \mathrm{sec} / \mathrm{scan}$ ) and processed using MassLynx software v.3.3. (Micromass). The mass/charge ratio of ions was deconvoluted to molecular mass using the MaxEnt3 algorithm. The amino acid sequences of tryptic peptides were deduced from series of $b$ and $y$ ions fragments produced by collision induced dissociation mass spectrometry (CID-MS/MS). The tryptic peptides of p65 were also analyzed by MALDI-TOF/TOF-MS using 4 hidroxy-cinamic acid as MALDI matrix (5 mg/ml) in $0.1 \%$ TFA in $50 \%$ acetonitrile. Peptide sequencing was obtained by high energy collision induced dissociation at $20 \mathrm{keV}$ and using helium as collision gas. All mass spectra from ESI-3Q and MALDI-TOF/TOF were submitted to databank search using MASCOT against nrNCBI, Swiss-Prot and squid ESTs.

\section{Sequence analyses}


The BLAST algorithms package (Altschul et al., 1990) was used locally in a Linux OS server to search for sequence similarities with the peptides extracted from the mass spectrometry analysis. BLASTp (peptides versus NCBI non-redundant protein database), tBLASTn (peptides versus Loligo pealei ESTs), and BLASTx (positive Loligo pealei ESTs matches versus NCBI nr protein database) searches were carried out using the most sensible parameters: wordsize $=2$, lowcomplexity-regions filter off and $e$-Value $=10$ ). Multiple sequence alignments were done using the ClustalW algorithm (Higgins and Sharp, 1989).

\section{Cytoplasmic ribonucleoprotein preparation and RNase assay}

Water for the solutions used here was treated with DEPC (1 ml per liter), left overnight and then autoclaved to destroy the DEPC. Ten optic lobes were homogenized in $3 \mathrm{ml}$ of cold homogenization buffer containing $50 \mathrm{mM}$ HEPES, pH 7.5, $125 \mathrm{mM} \mathrm{NaCl}, 100 \mathrm{mM}$ sucrose, $2 \mathrm{mM}$ potassium acetate, protease inhibitors and 40 units/ml of RNAse Out (Invitrogen) with a motordriven, Teflon-glass homogenizer by 10 strokes followed by a one min rest on ice and a second set of 10 strokes. The homogenate was centrifuged at 4,000 x g for $2 \mathrm{~min}$ and the supernatant (postnuclear fraction) was centrifuged at $14,000 \mathrm{x} \mathrm{g}$ for $10 \mathrm{~min}$. Three $\mathrm{ml}$ of this supernatant (postmitochondrial fraction) was diluted with $4.5 \mathrm{ml}$ of lysis buffer ( $83 \mathrm{mM}$ Tris-HCl, $\mathrm{pH} 7.5$, containing 1.7\% NP40, $6.6 \mathrm{mM} \mathrm{MgCl} 2,1.7 \mathrm{mM}$ DTT and $75 \mu \mathrm{g} / \mathrm{ml}$ cyclohexamide). After $10 \mathrm{~min}$ on ice, $3 \mathrm{ml}$ was applied to each of two discontinuous gradients made of $4.5 \mathrm{ml}$ of $12 \%$ and $34 \%$ sucrose in gradient buffer (50 mM Tris-HCl, pH 7.5, containing $50 \mathrm{mM} \mathrm{NaCl}, 4 \mathrm{mM} \mathrm{MgCl} 2$ and $1 \mathrm{mM} \mathrm{DTT}$ ). The gradient was centrifuged at 202,000 $\mathrm{x}$ g in a swinging bucket rotor (40Ti, Beckman) for $90 \mathrm{~min}$ at $4^{\circ} \mathrm{C}$. The fraction at the $12 \%$ sucrose upper interfase containing non-translated hnRNPs (Angenstein et al., 2005) was collected and diluted 1:1 in gradient buffer. Aliquots containing or not RNase $(100 \mu \mathrm{g} / \mathrm{ml})$ were incubated for $30 \mathrm{~min}$ at room temperature and centrifuged at 400,000 x $\mathrm{g}$ (90Ti rotor, Beckman) for $20 \mathrm{~min}$. Supernatant and pellet fractions were analyzed for the presence of p65 by western blots. 


\section{Immunohistochemistry}

Fixed, 1mm transversal slices of optic lobes were included in Paraplast (Oxford Labwase, St Louis, MO) following the manufacture's instructions. Microtome slices of $10 \mu \mathrm{m}$ were cut, transferred to glass slides, de-parafinized and rehydrated by standard procedures. Slices were incubated in phosphate buffered saline (PBS) pH 7.4 containing $0.1 \mathrm{M}$ glycine for $30 \mathrm{~min}$ at $4^{\circ} \mathrm{C}$ to block aldehyde groups and then washed 3 times for $10 \mathrm{~min}$ in PBS. They were then incubated in the dark at room temperature for $30 \mathrm{~min}$ in methanol containing $0.9 \%$ hydrogen peroxide solution to inhibit endogenous peroxidase activity, followed by washing in PBS. The samples were permeabilized and blocked by incubation in PBS containing $1 \%$ Triton $\mathrm{X}-100,3 \%$ BSA and $0.5 \%$ sheep serum and then incubated for $1 \mathrm{hr}$ with primary antibodies ( $\mathrm{C} 4$ diluted 1:10 and antisynaptotagmin diluted $1: 100$ in PBS containing $0.1 \%$ Triton X-100, 3\% BSA and $0.5 \%$ sheep serum). After washing in PBS containing 0.1\% Triton X-100, the slices were incubated for $1 \mathrm{hr}$ with secondary antibodies conjugated to horse radish peroxidase (KPL, Gaithesburg, MD) diluted 1:400 in PBS containing 0.1\% Triton X-100, 3\% BSA and $0.5 \%$ sheep serum and developed using 3,3'-diaminobenzidina (DAB) as substrate.

\section{Immunofluorescence}

Fixed stellate ganglia were directionally placed on and submerged in Tissue Tek (EMS, Hatfield PA). The blocks were frozen on acetone in dry ice and stored at $-20^{\circ} \mathrm{C} .10$ micron slices were cut through the pre- and postsynaptic region of the giant synapse and placed on microscope slides. Fixed synaptosomes were adhered to glass microscope slides by incubation for $1 \mathrm{hr}$ and gently washed with PBS. Slides containing either synaptosomes or stellate ganglia were then incubated in $0.1 \mathrm{M}$ glycine, washed in PBS and blocked in $1 \mathrm{mg} / \mathrm{ml} \mathrm{BSA}, 1 \%$ goat serum and 1\% Triton X-100 in PBS for $1 \mathrm{hr}$ at room temperature. The slides were then washed with PBS containing $0.3 \%$ Triton X-100 and incubated with primary antibody in PBS containing $1 \mathrm{mg} / \mathrm{ml}$ BSA, $1 \%$ goat serum, and $0.3 \%$ Triton $\mathrm{X}-100$ for $2 \mathrm{hrs}$ at room temperature. The slides were washed in PBS and incubated with appropriate secondary antibody conjugated to Alexa 488 for $1 \mathrm{hr}$ 
and washed again. In the case where double-labeling for squid synaptotagmin was done, the slide was incubated at this time for $1 \mathrm{hr}$ with anti-syt-C2A conjugated to rhodamine and subsequently washed. The slides were mounted in Fluoromount G (EMS) diluted 2:1 in PBS and examined by confocal microscopy on a Leica Microsystems SP2 microscope (Mannheim, Germany).

\section{Other methods}

SDS-PAGE was performed using 4-20\% linear gradient minigels, except where indicated. Western blots were on reinforced nitrocellulose membranes as previously described (Costa et al., 1999). Two-dimensional gels were done using the Ettan IPGPhorII Isoelectric Focusing System for the first dimension following the manufacturer's instructions (GE Healthcare) and SDS-PAGE, 8\% large gels, for the second dimension.

\section{Results}

The C4 antibody is immunoreactive to $p 65$ on immunoblots and by immunoprecipitation from extracts of squid optic lobes

Two affinity-purified, polyclonal antibodies raised against chicken myosin $\mathrm{Va}$, one generated against the head domain (referred to as $\mathrm{C} 4)$ and the other against the medial tail domain $(\alpha-$ MVaMT), both expressed in bacteria, were used in a western blot screen for interspecies immunoreactivity (Fig. 1A). A polypeptide corresponding to the myosin Va heavy chain $(\sim 200 \mathrm{k})$ was detected by $\alpha$-MVaMT in extracts from mouse, rat and chick brain as well as from squid optic lobes. Although the $\mathrm{C} 4$ antibody was also immunoreactive towards myosin Va heavy chain in the vertebrates, it did not recognize the corresponding band in squid. However, it did strongly label a 65 $\mathrm{kDa}$ polypeptide (p65) in optic lobe extracts. This peptide was also immunoprecipitated from optic lobe extracts by the C4 antibody (Fig. 1B) but not by $\alpha$-MVaMT. Squid myosin V was not immunoprecipitated by either of the antibodies. These results were the same if done on frozen optic lobes from Loligo pealei obtained from the Marine Biological Laboratory in Woods Hole, MA, 
USA or from Loligo plei obtained from the Marine Biology Center of the University of São PauloCEBIMar, São Sebastião, Brazil and indicate that both denatured and cellular forms of p65 are immunoreactive to the $\mathrm{C} 4$ antibody.

p65 was purified by cation exchange and reverse phase chromatography

In order to identify p65, a purification protocol that started from an extract of optic lobes in 8 M urea was developed, which included ion-exchange chromatography on SP-Sepharose (supplementary Fig.S1) and reverse phase FPLC on a Source 5RPC column (supplementary Fig.S2). When the urea extract was applied to the SP-Sepharose column, p65 was not detected in the flow-through fraction and was eluted from the column in about $800 \mathrm{mM}$ salt, indicating that it is a strongly basic protein. Since only a tenuous Coomassie-stained band could be detected in the peak fractions from the ion exchange column after SDS-PAGE that correlated to immunoreactivity on western blots (Fig. 2A), we conclude that p65 is not an abundant protein in optic lobes. In a fraction from the FPLC reverse phase column, however, p65 was isolated and concentrated, allowing it to be seen as a prominent protein band that was immunoreactive to C4 (Fig. 2B). This band was cut from the gel and analyzed by mass spectroscopy. Furthermore, on two dimensional gels (Fig. 2C and Supplementary Fig. S3) p65 was detected as a tight group of spots with pIs of 9.1 to 9.5 , confirming its basic nature and revealing the presence of potential isoforms.

\section{Peptide analysis indicated that p65 is a member of the hnRNP A/B subgroup of RNA binding} proteins

Peptide sequences were obtained from mass spectroscopy analysis of the tryptic digestion of p65. Adjusting parameters for short input sequences we ran the BLASTp program against the NCBI non-redundant (nr) protein database (Table). This analysis suggested that p65 is an RNA-binding protein containing the well-defined, RNA recognition motifs, RNP-1 (RGFGFITY) and RNP-2 (LFIGGL), as well as glycine-rich sequences, commonly found in the C-terminal region of these 
proteins. Sequences indicating a synaptic, calcium-binding motif and secreted protein with zinc finger motif were also found, suggesting a synaptic/exocytotic regulated function for $\mathrm{p} 65$. Since there are very few sequences corresponding to squid proteins in public data bases, we took advantage of a squid data bank in formation (DeGiorgis et al., manuscript in preparation) containing $\sim 23,000$ ESTs from Loligo pealei to search for nucleotide sequences corresponding to the p65 peptides. Running locally the tBLASTn algorithm we identified five ESTs that showed significant, but not exact, alignment with peptides 1 and 6 (Fig. 3). Using these five Loligo pealei ESTs in a BLASTx search against the NCBI nr protein database, we obtained strong correspondence to many hnRNPs, subtypes A/B, in species ranging from Drosophila to humans. This subset of RNAbinding proteins is also characterized by glycine-rich sequences in their c-terminal region, thus reinforcing the significance of peptides 4, 5 and 7 found in p65 (Table). Also, it has been reported that $21 \%$ of hnRNPs contain a zinc-finger domain (Maris et al., 2005), giving further significance to peptide 3 in the Table.

p65 is associated with hnRNP particles from cytoplasmic extracts in an RNA dependent manner.

In order to verify if p65 from tissue extracts is a cytoplasmic protein physically associated with RNA, a post nuclear and post mitochondrial fraction from optic lobes was obtained and applied on a sucrose gradient (Angenstein et al., 2005). The first interfase over $12 \%$ sucrose, enriched in hnRNP complexes, but not polysomes, contained p65 (Fig. 4, lane I). Since hnRNP complexes are labile to RNase treatment, this interfase fraction was collected, treated with RNase or not, and then centrifuged at high speed to separate the soluble and particulate fractions (Fig. 4). Without RNase treatment the pellet contained p65 whereas after treatment with RNase only traces of p65 were detected in the precipitated fraction, giving supporting evidence that tissue p65 is indeed part of a cytoplasmic hnRNP complex. Immunohistochemistry and immunofluorescence studies indicated that p65 is found in presynaptic structures 
To determine the localization of p65 in optic lobes, histological slices were incubated with the C4 antibody or anti-synaptotagmin and developed by the peroxidase-DAB method. Both antibodies labeled correspondingly-aligned bands within the outer plexiform layer (Fig. 5), which is a region of synaptic connections (Haghighat et al., 1984) particularly involving the photoreceptor terminations. Since synaptotagmin is a well-characterized, synaptic vesicle protein, the corresponding banding of the $\mathrm{C} 4$ antibody suggests a presynaptic location for $\mathrm{p} 65$ also. To further pinpoint the subcellular localization of $\mathrm{p} 65$, synaptosomes isolated from optic lobes were probed with $\mathrm{C} 4$ and control antibodies by western blots and by immunofluorescence microscopy. C4 clearly labeled p65 in blots of synaptosome extracts (Fig 6D). By immunofluorescence, large synaptosomes, 5-8 microns in diameter, showed intense granular staining by $\mathrm{C} 4$ frequently close to the plasma membrane, which correlated to subcellular structures imaged by bright field microscopy (Fig. 6A). Shown in Fig 6B and C are two controls - C5, an independent polyclonal antibody from a rabbit serum that was not immunoreactive to p65 on western blots (Fig. 6D) and the secondary antibody alone - that do not label the synaptosomes. Tissue slices through the giant synapse of the squid stellate ganglion showed intense labeling by anti-synaptotagmin, a marker for synaptic vesicles (Mikoshiba et al., 1995;Fukuda et al., 1995;Sugimori et al., 1998), on a strip between pre and post synaptic terminals (Fig. 7A), identifying it as the inner side of the presynaptic membrane and showing that it was accessible to the primary antibodies. At higher magnification with double labeling, irregular "puffy" dots were seen by anti-synaptotagmin (Fig 7B) suggestive of synaptic vesicle clusters, as expected for this protein. Strong staining for C4 was also observed over the presynaptic region (Fig 7C) although in smaller granules that frequently overlapped with the synaptotagmin clusters or were close near-neighboring particles to the clusters (Fig. 7D and E). The data confirm the presence of p65 at the presynaptic terminal and indicate a close spatial relationship to synaptic vesicle clusters.

\section{Discussion}


We have presented evidence that an affinity purified, polyclonal antibody, referred to as $\mathrm{C} 4$, raised against the head domain of chicken MVa is immunoreactive towards a highly basic, $65 \mathrm{k}$ protein (p65) purified from squid optic lobes. Since this antibody had a high degree of specificity for p65 in squid extracts but was not reactive towards squid myosin V, we sought to identify p65 by biochemical and immunological techniques. Peptide sequences, obtained from purified p65 by mass spectrometry and analyzed by BLAST algorithms, indicated that p65 is an RNA-binding protein, member of the hnRNP family, subtype A/B. Characteristics of this subtype are a basic protein having pIs of 8-9, the presence of two or more RNA recognition motifs (RNP-1 e RNP-2) and a glycine-rich accessory domain. About $21 \%$ have additional motifs such as zinc finger domains (Maris et al., 2005). All of these features were found in p65. Immunolocalization studies showed p65 within the outer plexiform layer and in large presynaptic terminals biochemically isolated from the photoreceptor neurons of squid optic lobes, as well as being closely associated with synaptic vesicle clusters at the presynaptic terminal of the giant synapse in the stellate ganglion. Thus, we have identified a novel $65 \mathrm{k}$ RNA-binding protein, present in squid presynaptic terminals.

A first question is why would an affinity-purified antibody raised against chicken myosin $\mathrm{Va}$ specifically recognize a non-related protein in squid neuronal tissue. Irrelevant, random, cross reactivity may be the simple answer and further speculation, at first thought, not worth pursuing. However, curiously, a polyclonal antibody, raised against the peptide LASNPIMESFGNAK found in the head domain of squid myosin $\mathrm{V}$, weakly labeled purified squid myosin $\mathrm{V}$ on western blots and strongly labeled a "55 k protein" on these same blots (Molyneaux and Langford, 1997), apparently a contaminant in the myosin $\mathrm{V}$ preparation, as commented by these authors. This peptide from squid is highly conserved and is identical, except for a single amino acid substitution ( $\mathrm{F}$ to I at peptide position 10), to one found in the head domain of chicken MVa. Since the C4 antibody used in the present work was raised against the head domain of chicken MVa, the same, or practically the same, antigenic determinant was present for the generation of both the squid peptide antibody and C4. We speculate that the "55 k immunoreactive protein" seen by Molyneaux and Langford is the 
same as the p65 identified here, which leads us to suggest that there is, in fact, a defined structural basis for this cross reactivity. With the present information in the public data banks a BLAST search with this peptide gave only myosin V hits, nothing that hinted of RNA-binding proteins. Full sequence determination of $\mathrm{p} 65$, now in progress, may give clues as to the nature of the antigenic determinant and possible evolutionary significance.

The suspicion of a structural basis for the cross reactivity described here and of possible evolutionary relevance is augmented by recent evidence that myosin $\mathrm{V}$ is involved in the transport and cytoplasmic localization of mRNAs; thus far, the only myosin class shown to have this function. The first and most detailed example in the literature is the role that yeast Myo4p, one of two myosin Vs in Saccharomyces cerevisiae, plays in the translocation of ASH1 mRNA into the bud tip (Gonsalvez et al., 2005;Pruyne et al., 2004;Muller et al., 2007). Recently, the other yeast myosin V, Myo2p, has also been implicated as a molecular motor component of a large messenger ribonucleoprotein (mRNP) complex associated with cytoplasmic P-bodies (Chang et al., 2008). In vertebrates, MVa has been associated with several RNA binding particles, for example, a mRNP complex containing Pura, mStaufen and Fragile X Mental Retardation Protein (Ohashi et al., 2002). Also, periaxoplasmic ribosomal plaques, discrete ribosome-containing domains found along myelinated axons, contain both MVa protein and its mRNA (Calliari et al., 2002;Sotelo-Silveira et al., 2004). Finally, MVa has been shown to associate with TLS (translocated in liposarcoma), a RNA-binding protein that is part of a large mRNP complex involved in transport and translation of mRNAs into dendrites (Yoshimura et al., 2006). In MVa-deficient hippocampal neurons, TLS cannot accumulate in spines upon glutamate receptor activation. Thus, these data indicate that there are functional associations between MVa, RNA, and RNA-binding proteins.

The hnRNPs form a large, diverse and structurally conserved family of proteins that are essential components of the multi-component RNA-protein complexes involved in the processing, regulation, translocation and stability of mRNAs (Maris et al., 2005;Dreyfuss et al., 2002;Dreyfuss et al., 1993). Members of the A/B subset of hnRNPs are highly conserved from invertebrates to mammals and characteristically shuttle between the nucleus and cytoplasm, but also are involved in the localization 
and stability of mRNA and regulation of its translation at distant subcellular sites. In neurons, many different mRNAs encoding synaptic proteins are targeted to the synaptic region and translated locally. Upon arrival, at least two events must occur: the liberation of specific mRNAs from granule repression and the activation of the local synthesis machinery. For example, in mammals hnRNP A2 is an essential component in a large multi-component granule that transports mRNAs away from the nucleus along microtubules out to dendrites (Carson et al., 2008). Translation of these mRNAs during transport is repressed by another RNA-binding protein, hnRNP E1. Once at their destinations, local control over translation of these transported mRNAs has been related to synaptic activity and plasticity. The mRNA encoding calmodulin-dependent protein kinase II (CaMKII), for example, is transported via this A2 pathway to dendrites where its local synthesis, stimulated by NMDA receptor activation, is required for long-term potentiation (Miller et al., 2002). Antagonists of the NMDA receptor inhibit CaMKII synthesis (Wells et al., 2000), thus illustrating the link between synaptic activity, local protein synthesis and synaptic plasticity. It is remarkable that an increase in the synthesis of CaMKII upon tetanic stimulation has been detected as early as 5 min post-stimulation in hippocampal slices (Ouyang et al., 1999). Similarly, a type of long-term depression, triggered by metabotropic glutamate receptor activation in hippocampal cells, requires the rapid translation (within 60 min of activation) of preexisting mRNA in the postsynaptic dendrites (Huber et al., 2000).

These examples of activity-related control on synaptic protein synthesis have mostly been demonstrated in dendrites (Wells, 2006). There is still a paucity of information on the function and regulation of the translation of the numerous mRNAs that have been identified specifically in the presynaptic terminals. (Gioio et al., 2004;Kaplan et al., 2004;Giuditta et al., 2002;Jimenez et al., 2002; Sotelo-Silveira et al., 2006;Alvarez et al., 2000), although invertebrate models offer some information. Long-term sensitization in Aplysia neurons elicited by serotonin was blocked by protein synthesis inhibitors injected into the sensory neuron but not when injected into the postsynaptic motor neuron (Martin et al., 1997). Furthermore, levels of protein synthesis in synaptosomes from squid optic lobes were altered by manipulation of intracellular calcium levels (Benech et al., 1999). These examples support the hypothesis that local translation and regulation of specific mRNAs at the presynaptic 
terminal is intimately related to synaptic activity and plasticity, as has been more clearly evidenced in dendrites. Based on this panorama and on our data presented here, we suggest that p65 is a novel link at the presynaptic terminal between local RNA processing and synaptic function, and as such represents an important new lead towards factors involved in synaptic plasticity.

\section{Acknowledgements}

We thank Domingos Pitta, Silvia Regina Andrade Nascimento, Maria Tereza Picinoto Maglia and Vani Maria Alves Correa for expert technical assistance. Special thanks to Dr. Thomas Reese, National Institute of Neurological Disorders and Strokes, NIH, in whose laboratory several critical experiments on Loligo pealei were first done. Live Loligo plei were obtained from the Centro de Biologia Marinha da Universidade de São Paulo (CEBIMar). REL, JCR and JEM received financial support from the Fundação de Amparo à Pesquisa do Estado de Sao Paulo (FAPESP), the Conselho Nacional de Desenvolvimento Científico e Tecnológico (CNPq) and the Fundação de Apoio ao Ensino, Pesquisa e Assistência do Hospital das Clínicas da FMRP-USP (FAEPA). JAD received financial support from the RI-INBRE Program Grant \#P20RR016457 from the Nation Center for Research Resources, NIH, Bethesda, MD. DTPL, LC, SBFT, EJRV and MMAB were recipients of research fellowships from FAPESP and CNPq. REL and JEM received Productivityin-Research fellowships from CNPq. The confocal work was performed on Leica microscopes in the Laboratório Multiusuário de Microscopia Confocal do Departamento de Biologia Celular e Molecular e Bioagentes Patogênicos-FMRP/USP under the technical supervision of Dr. Lenaldo Branco Rocha. 
Reference List

Altschul SF, Gish W, Miller W, Myers EW, Lipman DJ (1990) Basic local alignment search tool. J Mol Biol 215:403-410.

Alvarez J, Giuditta A, Koenig E (2000) Protein synthesis in axons and terminals: significance for maintenance, plasticity and regulation of phenotype. With a critique of slow transport theory. Prog Neurobiol 62:1-62.

Angenstein F, Evans AM, Ling SC, Settlage RE, Ficarro S, Carrero-Martinez FA, Shabanowitz J, Hunt DF, Greenough WT (2005) Proteomic characterization of messenger ribonucleoprotein complexes bound to nontranslated or translated poly(A) mRNAs in the rat cerebral cortex. J Biol Chem 280:6496-6503.

Benech JC, Crispino M, Kaplan BB, Giuditta A (1999) Protein synthesis in presynaptic endings from squid brain: modulation by calcium ions. J Neurosci Res 55:776-781.

Brown JR, Stafford P, Langford GM (2004) Short-range axonal/dendritic transport by myosin-V: A model for vesicle delivery to the synapse. J Neurobiol 58:175-188.

Calliari A, Sotelo-Silveira J, Costa MC, Nogueira J, Cameron LC, Kun A, Benech J, Sotelo JR (2002) Myosin Va is locally synthesized following nerve injury. Cell Motil Cytoskeleton 51:169176.

Carson JH, Gao Y, Tatavarty V, Levin MK, Korza G, Francone VP, Kosturko LD, Maggipinto MJ, Barbarese E (2008) Multiplexed RNA trafficking in oligodendrocytes and neurons. Biochimica et Biophysica Acta (BBA) - Gene Regulatory Mechanisms 1779:453-458.

Chang W, Zaarour RF, Reck-Peterson S, Rinn J, Singer RH, Snyder M, Novick P, Mooseker MS (2008) Myo2p, a class V myosin in budding yeast, associates with a large ribonucleic acid-protein complex that contains mRNAs and subunits of the RNA-processing body. RNA 14:491-502.

Cheney RE (1998) Purification and assay of myosin V. Methods Enzymol 298:3-18.

Cohen DL (2001) Squid p196, a new member of the myosin-V class of motor proteins, is associated with motile axoplasmic organelles. Brain Research 890:233-245.

Correia SS, Bassani S, Brown TC, Lise MF, Backos DS, El-Husseini A, Passafaro M, Esteban JA (2008) Motor protein-dependent transport of AMPA receptors into spines during long-term potentiation. Nat Neurosci 11:457-466.

Costa MC, Mani F, Santoro W, Jr., Espreafico EM, Larson RE (1999) Brain myosin-V, a calmodulin-carrying myosin, binds to calmodulin-dependent protein kinase II and activates its kinase activity. J Biol Chem 274:15811-15819.

Crispino M, Capano CP, Kaplan BB, Giuditta A (1993) Neurofilament proteins are synthesized in nerve endings from squid brain. J Neurochem 61:1144-1146.

Crispino M, Kaplan BB, Martin R, Alvarez J, Chun JT, Benech JC, Giuditta A (1997) Active polysomes are present in the large presynaptic endings of the synaptosomal fraction from squid brain. J Neurosci 17:7694-7702. 
Desnos C, Huet S, Darchen F (2007) 'Should I stay or should I go?': myosin V function in organelle trafficking. Biol Cell 99:411-423.

Dreyfuss G, Matunis MJ, Pinol-Roma S, Burd CG (1993) hnRNP proteins and the biogenesis of mRNA. Annu Rev Biochem 62:289-321.

Dreyfuss G, Kim VN, Kataoka N (2002) Messenger-RNA-binding proteins and the messages they carry. Nat Rev Mol Cell Biol 3:195-205.

Espreafico EM, Cheney RE, Matteoli M, Nascimento AA, De Camilli PV, Larson RE, Mooseker MS (1992) Primary structure and cellular localization of chicken brain myosin-V (p190), an unconventional myosin with calmodulin light chains. J Cell Biol 119:1541-1557.

Fukuda M, Moreira JE, Lewis FM, Sugimori M, Niinobe M, Mikoshiba K, Llinas R (1995) Role of the $\mathrm{C} 2 \mathrm{~B}$ domain of synaptotagmin in vesicular release and recycling as determined by specific antibody injection into the squid giant synapse preterminal. Proc Natl Acad Sci U S A 92:1070810712.

Gioio AE, Lavina ZS, Jurkovicova D, Zhang H, Eyman M, Giuditta A, Kaplan BB (2004) Nerve terminals of squid photoreceptor neurons contain a heterogeneous population of mRNAs and translate a transfected reporter mRNA. Eur J Neurosci 20:865-872.

Giuditta A, Kaplan BB, van MJ, Alvarez J, Koenig E (2002) Axonal and presynaptic protein synthesis: new insights into the biology of the neuron. Trends Neurosci 25:400-404.

Gonsalvez GB, Urbinati CR, Long RM (2005) RNA localization in yeast: moving towards a mechanism. Biol Cell 97:75-86.

Haghighat N, Cohen RS, Pappas GD (1984) Fine structure of squid (Loligo pealei) optic lobe synapses. Neuroscience 13:527-546.

Higgins DG, Sharp PM (1989) Fast and sensitive multiple sequence alignments on a microcomputer. Comput Appl Biosci 5:151-153.

Huber KM, Kayser MS, Bear MF (2000) Role for rapid dendritic protein synthesis in hippocampal mGluR-dependent long-term depression. Science 288:1254-1257.

Jansen RP, Dowzer C, Michaelis C, Galova M, Nasmyth K (1996) Mother cell-specific HO expression in budding yeast depends on the unconventional myosin myo4p and other cytoplasmic proteins. Cell 84:687-697.

Jimenez CR, Eyman M, Lavina ZS, Gioio A, Li KW, van der Schors RC, Geraerts WP, Giuditta A, Kaplan BB, van MJ (2002) Protein synthesis in synaptosomes: a proteomics analysis. J Neurochem 81:735-744.

Kaplan BB, Lavina ZS, Gioio AE (2004) Subcellular compartmentation of neuronal protein synthesis: new insights into the biology of the neuron. Ann N Y Acad Sci 1018:244-254.

Langford GM (2002) Myosin-V, a versatile motor for short-range vesicle transport. Traffic 3:859865 .

Mani F, Espreafico EM, Larson RE (1994) Myosin-V is present in synaptosomes from rat cerebral cortex. Braz J Med Biol Res 27:2639-2643. 
Maris C, Dominguez C, Allain FH (2005) The RNA recognition motif, a plastic RNA-binding platform to regulate post-transcriptional gene expression. FEBS J 272:2118-2131.

Martin KC, Casadio A, Zhu H, Yaping E, Rose JC, Chen M, Bailey CH, Kandel ER (1997) Synapse-specific, long-term facilitation of aplysia sensory to motor synapses: a function for local protein synthesis in memory storage. Cell 91:927-938.

Mikoshiba K, Fukuda M, Moreira JE, Lewis FM, Sugimori M, Niinobe M, Llinas R (1995) Role of the $\mathrm{C} 2 \mathrm{~A}$ domain of synaptotagmin in transmitter release as determined by specific antibody injection into the squid giant synapse preterminal. Proc Natl Acad Sci U S A 92:10703-10707.

Miller S, Yasuda M, Coats JK, Jones Y, Martone ME, Mayford M (2002) Disruption of Dendritic Translation of CaMKII[alpha] Impairs Stabilization of Synaptic Plasticity and Memory

Consolidation. Neuron 36:507-519.

Molyneaux BJ, Langford GM (1997) Characterization of antibodies to the head and tail domains of squid brain myosin V. Biol Bull 193:222-223.

Molyneaux BJ, Mulcahey MK, Stafford P, Langford GM (2000) Sequence and phylogenetic analysis of squid myosin-V: a vesicle motor in nerve cells. Cell Motil Cytoskeleton 46:108-115.

Muller M, Heuck A, Niessing D (2007) Directional mRNA transport in eukaryotes: lessons from yeast. Cell Mol Life Sci 64:171-180.

Ohashi S, Koike K, Omori A, Ichinose S, Ohara S, Kobayashi S, Sato TA, Anzai K (2002)

Identification of mRNA/protein (mRNP) complexes containing Puralpha, mStaufen, fragile $\mathrm{X}$ protein, and myosin $\mathrm{Va}$ and their association with rough endoplasmic reticulum equipped with a kinesin motor. J Biol Chem 277:37804-37810.

Ouyang Y, Rosenstein A, Kreiman G, Schuman EM, Kennedy MB (1999) Tetanic stimulation leads to increased accumulation of $\mathrm{Ca}(2+) /$ calmodulin-dependent protein kinase II via dendritic protein synthesis in hippocampal neurons. J Neurosci 19:7823-7833.

Pfeiffer BE, Huber KM (2006) Current advances in local protein synthesis and synaptic plasticity. J Neurosci 26:7147-7150.

Prekeris R, Terrian DM (1997) Brain myosin V is a synaptic vesicle-associated motor protein: evidence for a $\mathrm{Ca} 2+$-dependent interaction with the synaptobrevin-synaptophysin complex. J Cell Biol 137:1589-1601.

Pruyne D, Legesse-Miller A, Gao L, Dong Y, Bretscher A (2004) Mechanisms of polarized growth and organelle segregation in yeast. Annu Rev Cell Dev Biol 20:559-591.

Salerno VP, Calliari A, Provance DW, Jr., Sotelo-Silveira JR, Sotelo JR, Mercer JA (2008) MyosinVa mediates RNA distribution in primary fibroblasts from multiple organs. Cell Motil Cytoskeleton 65:422-433.

Schuman EM, Dynes JL, Steward O (2006) Synaptic regulation of translation of dendritic mRNAs. J Neurosci 26:7143-7146.

Sotelo-Silveira JR, Calliari A, Cardenas M, Koenig E, Sotelo JR (2004) Myosin Va and kinesin II motor proteins are concentrated in ribosomal domains (periaxoplasmic ribosomal plaques) of myelinated axons. J Neurobiol 60:187-196. 
Sotelo-Silveira JR, Calliari A, Kun A, Koenig E, Sotelo JR (2006) RNA trafficking in axons. Traffic 7:508-515.

Steward O, Schuman EM (2003) Compartmentalized synthesis and degradation of proteins in neurons. Neuron 40:347-359.

Sugimori M, Tong C-K, Fukuda M, Moreira JE, Kojima T, Mikoshiba K, Llinßs R (1998)

Presynaptic injection of syntaxin-specific antibodies blocks transmission in the squid giant synapse. Neuroscience 86:39-51.

Tabb JS, Molyneaux BJ, Cohen DL, Kuznetsov SA, Langford GM (1998) Transport of ER vesicles on actin filaments in neurons by myosin V. J Cell Sci 111 ( Pt 21):3221-3234.

Takamori S, et al. (2006) Molecular anatomy of a trafficking organelle. Cell 127:831-846.

Trybus KM (2008) Myosin V from head to tail. Cell Mol Life Sci 65:1378-1389.

Twiss JL, Fainzilber M (2009) Ribosomes in axons--scrounging from the neighbors? Trends Cell Biol 19:236-243.

Walikonis RS, Jensen ON, Mann M, Provance DW, Jr., Mercer JA, Kennedy MB (2000) Identification of proteins in the postsynaptic density fraction by mass spectrometry. $\mathrm{J}$ Neurosci 20:4069-4080.

Wells DG (2006) RNA-binding proteins: a lesson in repression. J Neurosci 26:7135-7138.

Wells DG, Richter JD, Fallon JR (2000) Molecular mechanisms for activity-regulated protein synthesis in the synapto-dendritic compartment. Curr Opin Neurobiol 10:132-137.

Yoshimura A, Fujii R, Watanabe Y, Okabe S, Fukui K, Takumi T (2006) Myosin-Va facilitates the accumulation of mRNA/protein complex in dendritic spines. Curr Biol 16:2345-2351. 
Table. Identification by mass spectrometry of tryptic peptides from p65. Purified p65 was excised from an $8 \%$ SDS-PAGE gel, digested with trypsin and analyzed by mass spectroscopy as described in Materials and Methods. Periods before or after the sequences in the table indicate that the extremities of the peptide could not be determined from the spectra.

\begin{tabular}{|c|c|c|c|}
\hline peptide & $\begin{array}{l}\text { peptide } \\
\text { mass } \\
\mathrm{Mr}\end{array}$ & sequence & BLAST search description \\
\hline 1 & 931.43 & GFGFITYK & hnRNP; glycine-rich RNA binding protein \\
\hline 2 & 1105.0 & LSTLDPESDK & $\begin{array}{l}\mathrm{Ca}^{2+} \text {-dependent lipid binding protein; } \mathrm{Ca}^{2+}- \\
\text { binding motif in phospholipase, prot.kinase } \mathrm{C} \\
\text { and synaptotagmin }\end{array}$ \\
\hline 3 & 1459.65 & YPSYGDSYGGGLPK & $\begin{array}{l}\text { Zinc finger; secreted protein with zinc-dependent } \\
\text { carboxypeptidase domain }\end{array}$ \\
\hline 4 & 1673.61 & .GGGGGGGGGGG. & $\begin{array}{l}\text { Glycine-rich RNA-binding protein; RNP } \\
\text { complex protein }\end{array}$ \\
\hline 5 & 1730.64 & .GGGGGGGGGGGG. & $\begin{array}{l}\text { Glycine-rich RNA-binding protein; RNP } \\
\text { complex protein }\end{array}$ \\
\hline 6 & 1913.92 & LFIGGLSYDTNEDTIKK & Cold-inducible RNA binding protein \\
\hline 7 & 2914.29 & .PWSFPGGGGYGGGGNFQ. & $\begin{array}{l}\text { Cellular nucleic acid binding protein; glycine- } \\
\text { rich RNA binding protein; cytoplasmic poly-A } \\
\text { binding protein } 4\end{array}$ \\
\hline
\end{tabular}




\section{Figure legends}

\section{Fig. 1. The C4 polyclonal antibody recognizes a $65 \mathrm{k}$ polypeptide in squid optic lobe extracts.}

(A) Western blots of tissue extracts from mouse, rat and chick brains, and squid optic lobes, probed with a polyclonal antibody raised against the head domain of chicken MVa (C4, upper panel), or a polyclonal antibody raised against the medial tail domain, anti-MVa-MT ( $\alpha-\mathrm{MT}$, lower panel), respectively. To the right of the blots, the $M_{r}$ positions of the heavy chain of myosin Va (hcMVa) and p65 are indicated. (B) Immunoprecipitation of p65 from squid optic lobe extracts by C4. Extracts of squid optic lobes were subjected to immunoprecipitation as described in Experimental Procedures and analyzed by Western blots probed with the C4 antibody. S1, input fraction; lane 1, fraction immunoprecipitated by $\mathrm{C} 4$ antibody; lane 2, fraction immunoprecipitated by $\alpha-\mathrm{MVa}-\mathrm{MT}$; lane 3 , fraction precipitated from the extract without antibody. The positions of p65 and IgG heavy chain are indicated to the right of the figure.

Fig. 2. p65 is a low-abundant, basic protein comprised of isoforms. (A) SDS-PAGE of the peak p65 fraction (38) from the SP-Sepharose column (see Supplementary Fig.S1) stained with Coomassie Blue-R (CB) and western blot (C4) probed with the C4 antibody. Molecular mass markers are indicated to the left. (B) SDS-PAGE on an 8\% gel of fractions 13 and 14 from the reverse phase chromatography (5RPC) (see Supplementary Fig.S2) stained with colloidal Coomassie Blue (CCB) and western blot (C4) probed with the $\mathrm{C} 4$ antibody. Molecular mass markers are shown and indicated to the left. (C) A section of a 2-D gel stained with silver of fraction 13 from the reverse phase column (left panel) and western blot of an equivalent gel probed with the $\mathrm{C} 4$ antibody (right panel). The $\mathrm{pI}$ range is given above the sections and potential isoforms are numbered 1-5. (The complete 2-D gel is shown in Supplementary Fig. S3)

\section{Fig. 3. Identification of ESTs in the Loligo pealei data base with peptides derived from p65.}

The open reading frames of ESTs from the Loligo data bank were converted to amino acid sequences using the tblastn program available from the NCBI site. Alignment between multiple sequences was performed via the ClustalW program. Only sequences 1 and 6 from the Table had 
significant homology within the available ESTs and their alignment with 5 ESTs are shown in the figure. The boxed sequences illustrate the consensus sequences for RNP 1 and RNP 2, as indicated. Identity between the peptide amino acids and at least 4 out of the 5 EST sequences is indicated by an asterisk below the alignment and chemically homologous amino acids by two dots.

Fig. 4. Biochemical evidence that p65 is associated with cytoplasmic RNP particles. SDSPAGE gel stained with Coomassie blue-R (upper panel) and western blot probed with C4 (lower panel) of a fraction (I) from optic lobe extracts prepared to preserve mRNP particles as described in Experimental Procedures. Aliquots of this fraction were treated with RNase $(+)$ or water ( - ), incubated for $30 \mathrm{~min}$ and then centrifuged at 400,000 x g for $20 \mathrm{~min}$. (S) and (P) indicate the supernatant and pellet fractions, respectively. p65 is indicated to the right of the bottom panel. Fig. 5. Immunohistochemistry of slices from squid optic lobes. Transversal, $10 \mu \mathrm{m}$ slices through the squid optic lobe were labeled with C4 (A), anti-synaptotagmin (B) or secondary antibody alone $(\mathrm{C})$ by the peroxidase-DAB method as described in Experimental Procedures. The arrows indicate the immunopositive bands for both primary antibodies in the outer plexiform layer (opx). The morphological layers of the optic lobe cortex as described by Haghighat et al. (1984) are indicated to the right: outer nuclear (on), outer plexiform (opx), inner nuclear (in), inner plexiform (ipx) and mononuclear (mn) layers.

Fig. 6. Immunofluorescence labeling of synaptosomes from squid optic lobes. (A) A gallery of confocal images of synaptosomes immunolabeled with C4 primary and Alexa 488 secondary antibodies (green) next to their DIC images is illustrated. (B) Control showing synaptosomes probed with a rabbit polyclonal antibody, $\mathrm{C} 5$, that was not immunoreactive to p65 on western blots, or (C) probed with the secondary antibody conjugate, anti-rabbit IgG/Alexa 488, alone. The scale bars represent 5 microns. (D) Western blots of extracts from synaptosomes stained with Coomassie blue $(\mathrm{CB})$ or probed with $\mathrm{C} 4$ or $\mathrm{C} 5$ antibodies, as indicated, or secondary alone $\left(2^{\text {nd }}\right)$. Molecular mass markers are indicated on the left. 
Fig. 7. Immunofluorescence labeling of the giant synapse of the stellate ganglion. A transversal histological slice of 10 microns through the stellate ganglion showing pre- and postsynaptic terminals of the giant synapse was double-labeled with the antibody C4 (green) and antisynaptotagmin (anti-syt-C2A, red). Control section was probed with only the Alexa 488 (green) conjugated secondary antibody, without primary antibody. (A) A low magnification image illustrating the localization of synaptotagmin on a strip between the pre- and postsynaptic terminals (pre and post, respectively). (B, C and D) Higher magnifications of the presynaptic strip with double labeling. Irregular clusters of presumed synaptic vesicles are labeled by anti-syt-C2A (red) whereas smaller particles distributed over the same area are labeled by $\mathrm{C} 4$ (green). (E) A blow up of the boxed area in D. The merged images (D and E) show frequent punctual overlap (yellow), some of which are indicated by arrows, as well as close contact (arrowheads) between these markers. The scale bars represent 10 microns. 


\section{Interspecies immunoreactivity of MVa antibodies}

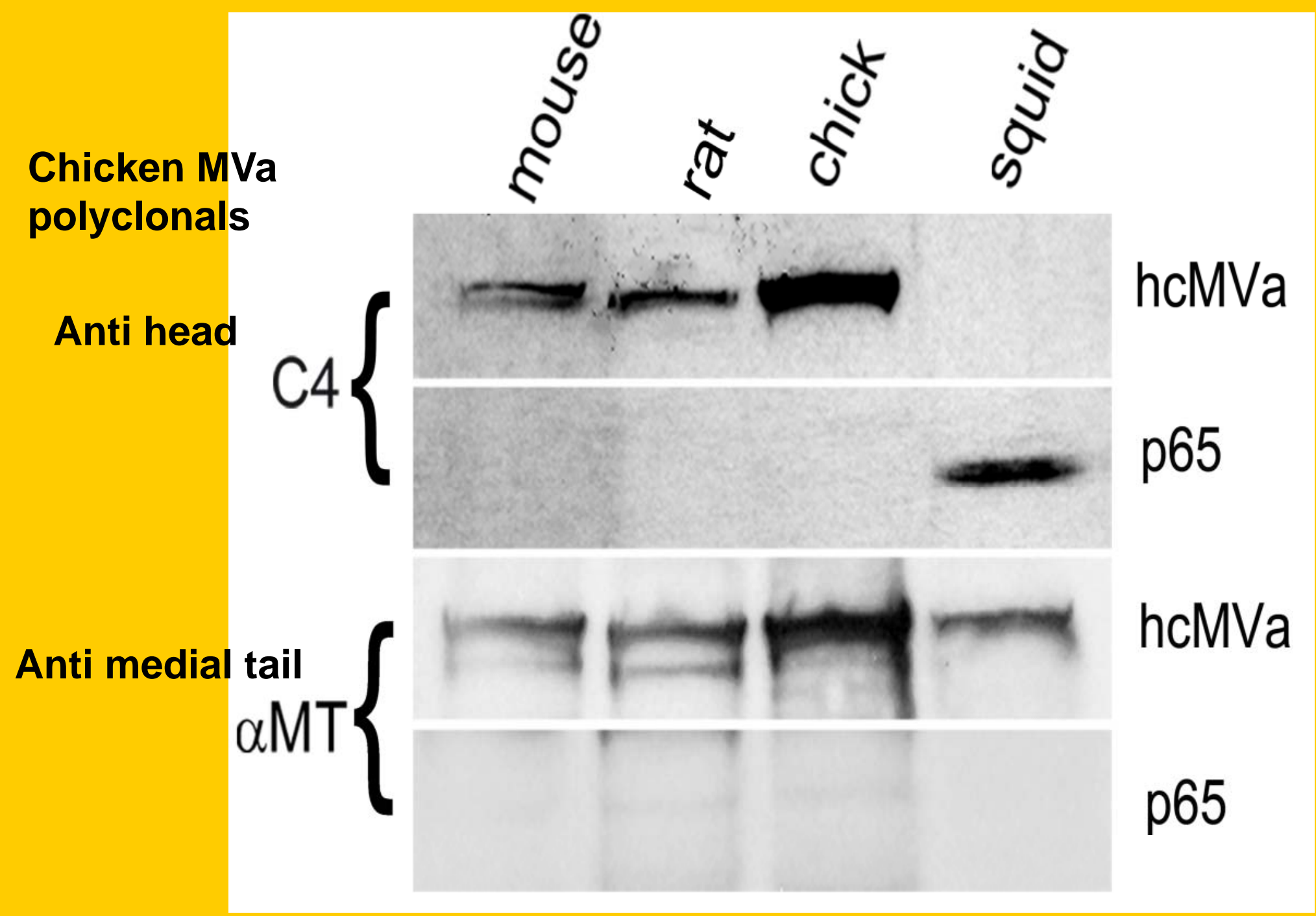

Figure 1A 


\section{Immunoprecipitation of p65 from squid optic lobes}

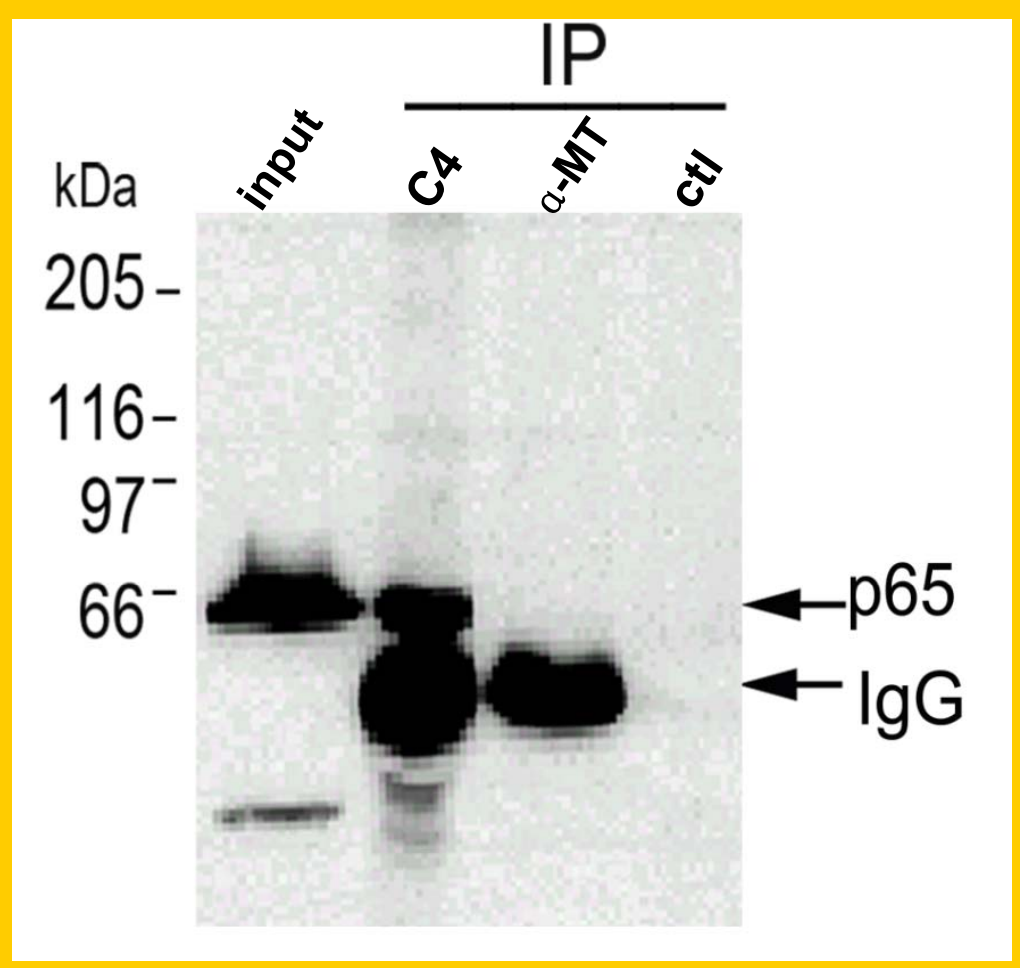

Figure 1B 


\section{Cationic exchange}

$\begin{array}{lll}\text { B } & \text { kDa } & \text { s2 FT } 32343639404244464850\end{array}$
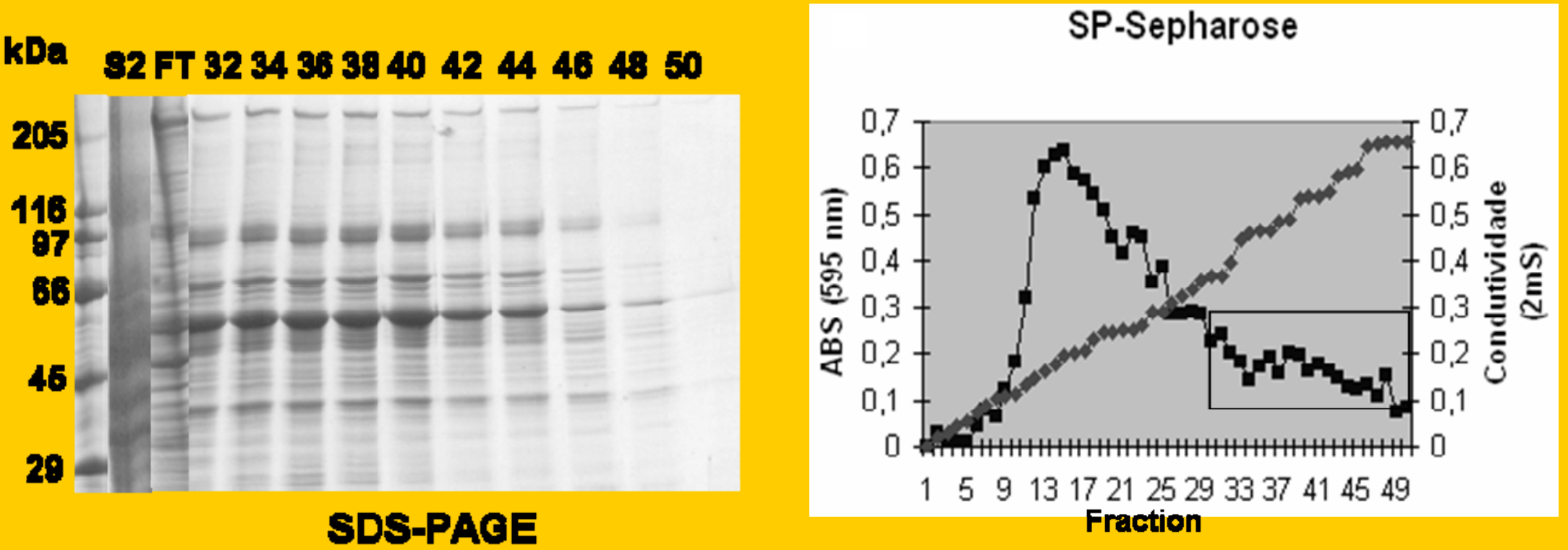

$\begin{array}{lllllllllllll}C & 52 & \text { FT } & 32 & 34 & 36 & 38 & 40 & 42 & 44 & 46 & 48 & 50\end{array}$

p65

Western blot

Figure S1 


\section{FPLC}

reverse phase

Figure S2
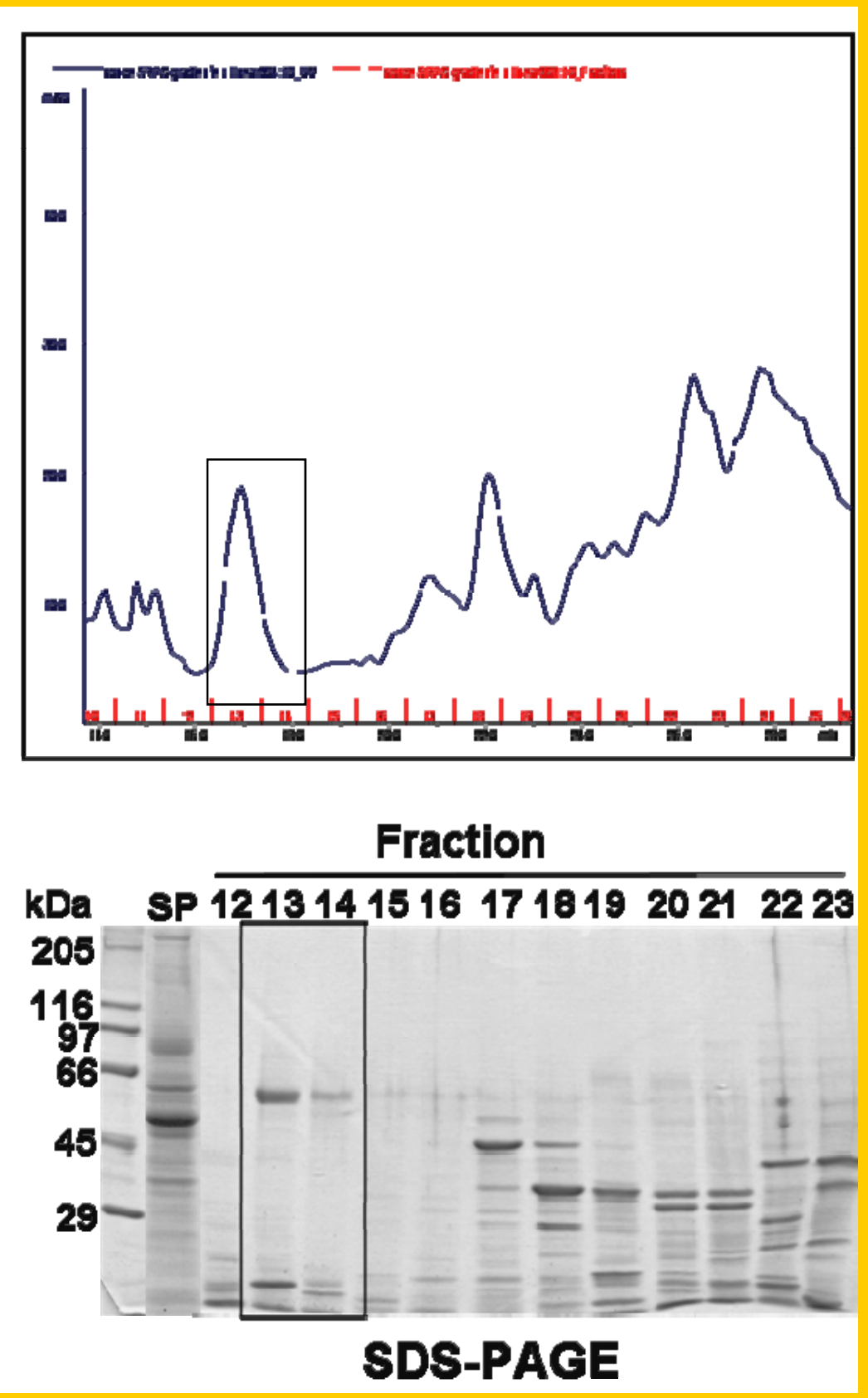
A B

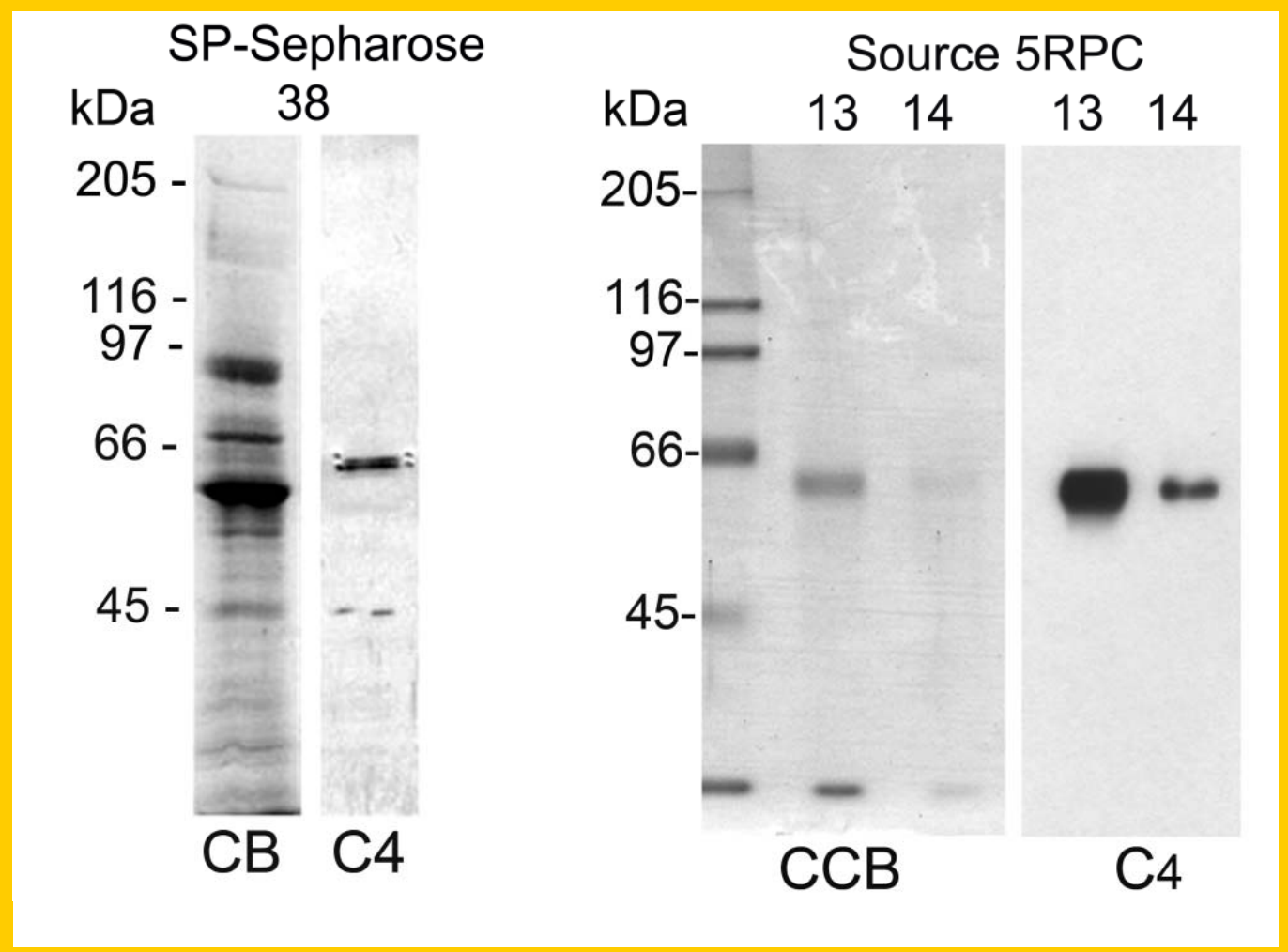

Figure 2 


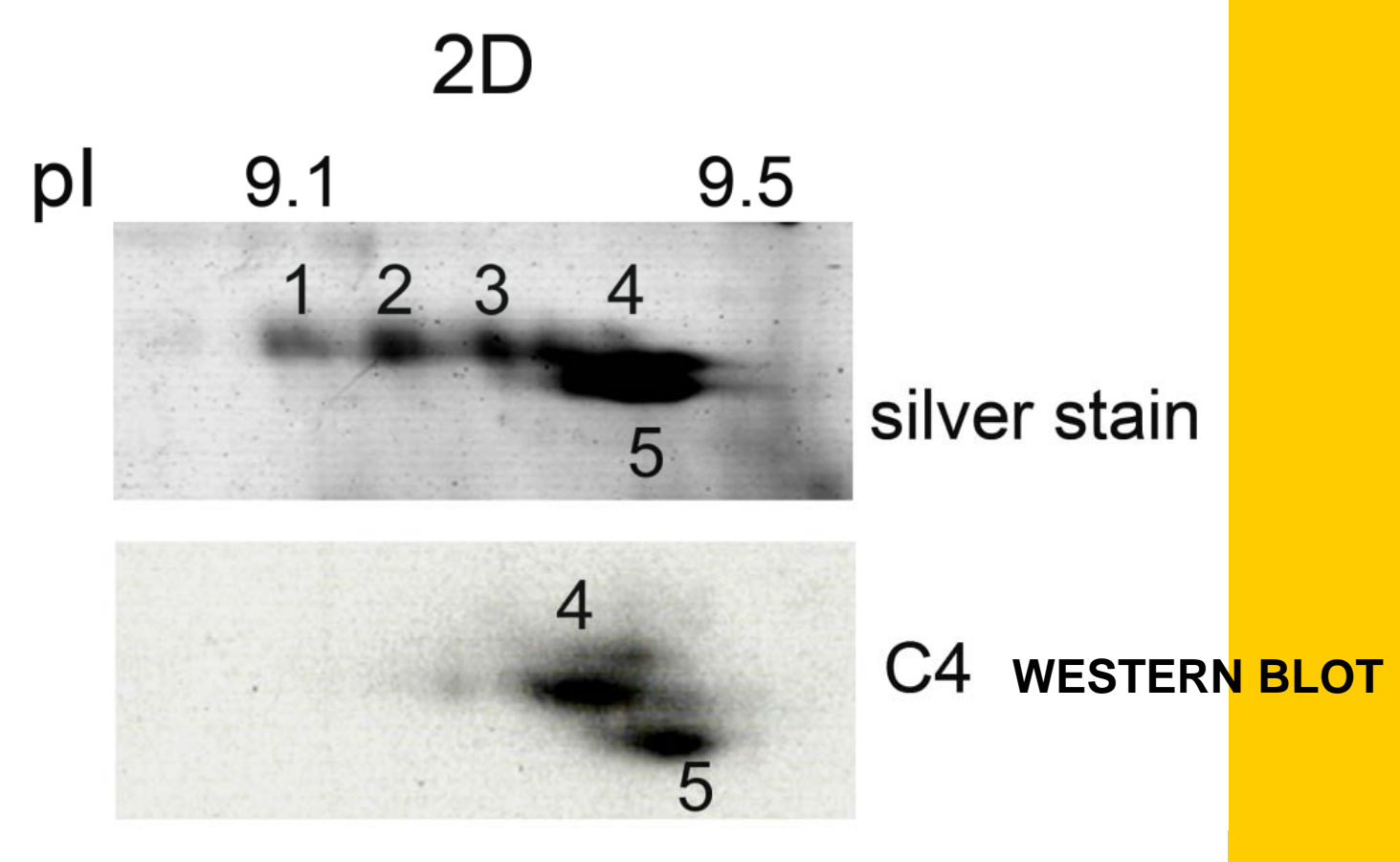

Figure 2C 


\section{ESTs from Loligo pealei}

\begin{tabular}{|c|c|}
\hline \multirow{2}{*}{$\begin{array}{l}\text { peptide } \\
\text { oy189g03.y3 }\end{array}$} & \\
\hline & \\
\hline & ---VRPRVRLTSVLGSLSLST TFN PSS LSGDIF L PCRGF FF PREILF SNNTGL \\
\hline & ----PKGAIMP-- \\
\hline & $-------E T L T Q F$ S SVST RT E SKRELSEGKRE KNWRTYIYR---------- \\
\hline & SEHIRHLCIF LLGE RLLYHKTEKTQKKLVSF LIF P PLS SETMT DF QT DPVEMDG: \\
\hline & 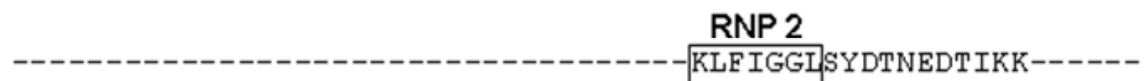 \\
\hline $189 \mathrm{~g} 03 . \mathrm{y3}$ & 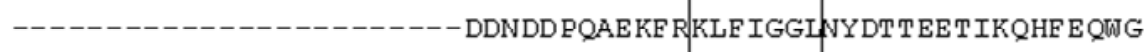 \\
\hline & LKRLT KTLFFGLQNM PKRMENGT SNHNDD PNAE KF R KLF IGGLNYDT T EDS LRTYF E QWG \\
\hline y3 & 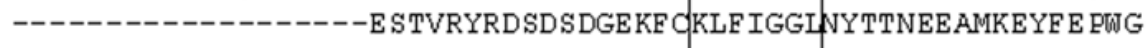 \\
\hline & --------YRLTHLY SKM PEF DQE QRYRDGEEE KY ELF IGGLNYTAT QE GLRGRE E QWG \\
\hline & NIDGHENSEEVVETF ES AMETMDDGDDKGNDDEESR KLFVGGISWET KAKDLREYFF KF G \\
\hline & 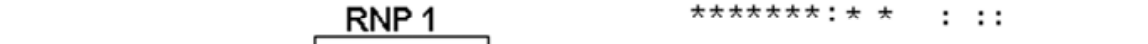 \\
\hline & 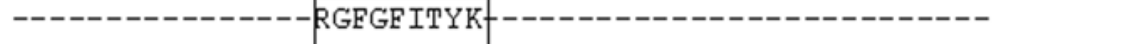 \\
\hline.$y^{3}$ & EIVDCVVMKNPATKKSRGEGE ITYKAAEMLDDAQTNRPHKI DNRE LDT KRAMPRNE SDE S \\
\hline & EVVDCVMMKNPSTNR SRGFGE ITYQ\$AEQLDDAQTNRPHTIDSKKLDT KRA \\
\hline & EVVDCVVMRDPNTKKSRGFGF ITYK KE EQVDE AQRNRPHNI DNKEVET KRAMPRNE \\
\hline & EIVD-DKMRDPVTG-GRGFGFVTYK中EEVLDDAHKNRPHKLDGTEVDTQRAII \\
\hline & EVEHCNLKT DPVTKRSBGEGFVLFKE EATVDKALLEKEHKLHGRNIDPKRANPR---- \\
\hline & 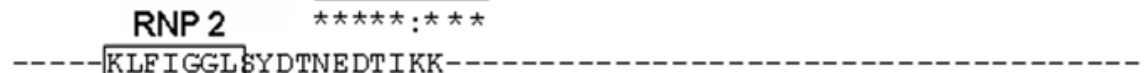 \\
\hline & QT SVKKMFVGGL KDDTAE DDVREVFGRFGKIE KLEMIKDKNT GKQRGE CF I TF DDF DCVD \\
\hline & A.SVKKMFVGGLEETTSE DEIRDIF SKYGTVE KVDMIKDKNT GKQKRF CFVTF DDF DAVD \\
\hline $189 c 02 \cdot y^{3}$ & QATVKKLFVGGIKEDTSEEEIREFFSTKGKIE SIDMITDKGT GKKRGF CF ITF E DYDTVD \\
\hline . 11 & QATVEKMFVGGL \\
\hline y225b06.y1 & 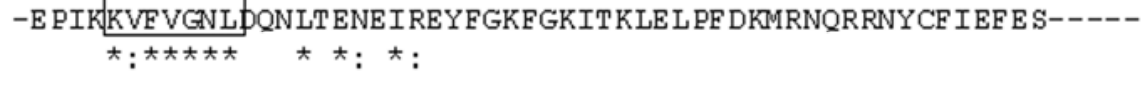 \\
\hline & - \\
\hline & CVLKRRIF PHG \\
\hline $95 \mathrm{~d} 11 \cdot \mathrm{y}^{1}$ & KCVIRKRE PLGSKSI---------- \\
\hline 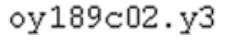 & LVLKKYLDFKGKRVEVKKLLSELK \\
\hline & \\
\hline & \\
\hline
\end{tabular}

hnRNP A/B

Figure 3 


\section{P65 IS ASSOCIATED WITH CYTOPLASMIC RNP PARTICLES VIA RNA}

Post-nuclear, post-mitochondrial fraction Applied to discontinuous sucrose gradient
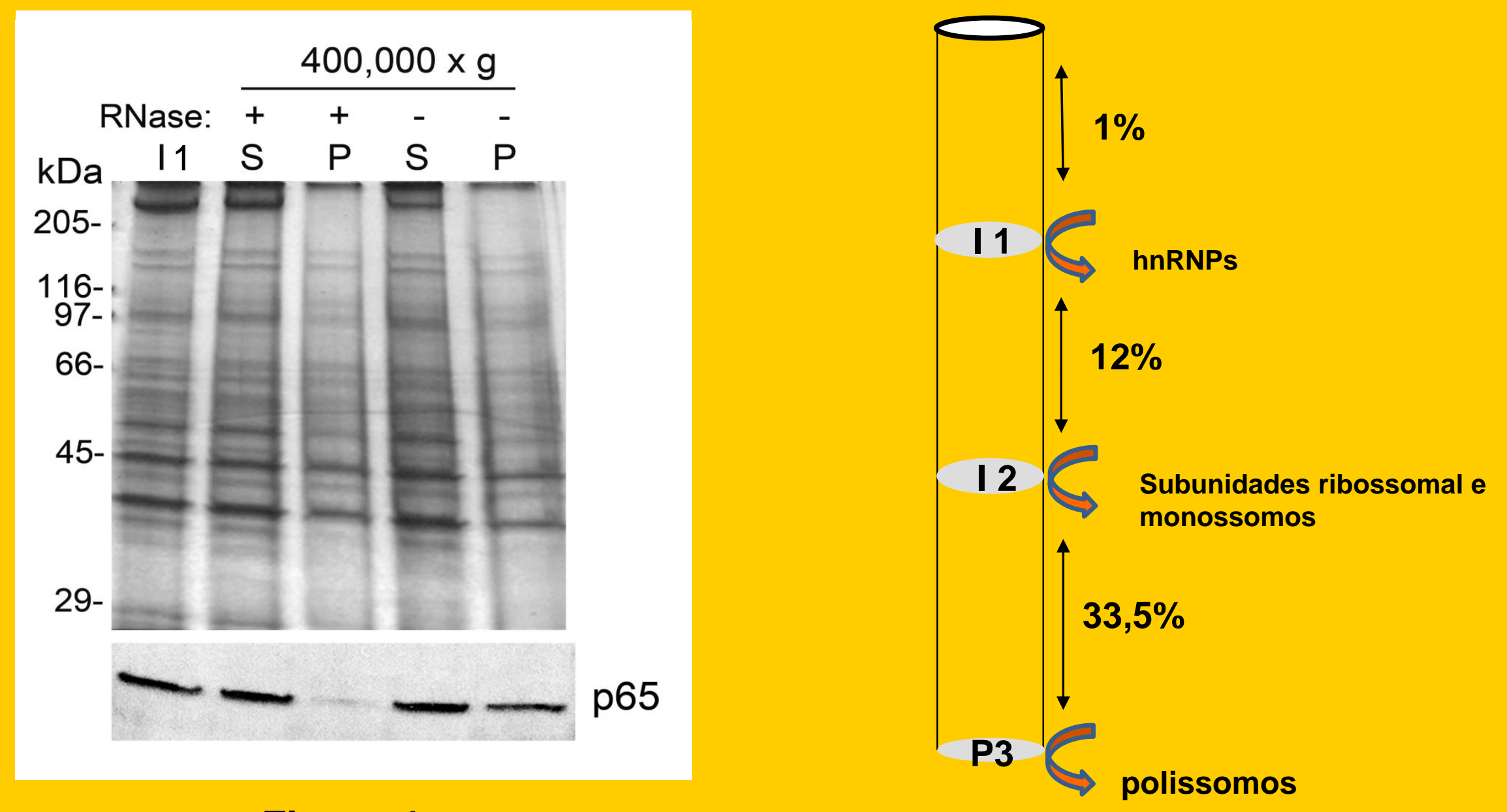

Figure 4 


\section{Immunohistochemistry of slices from squid optic lobes}

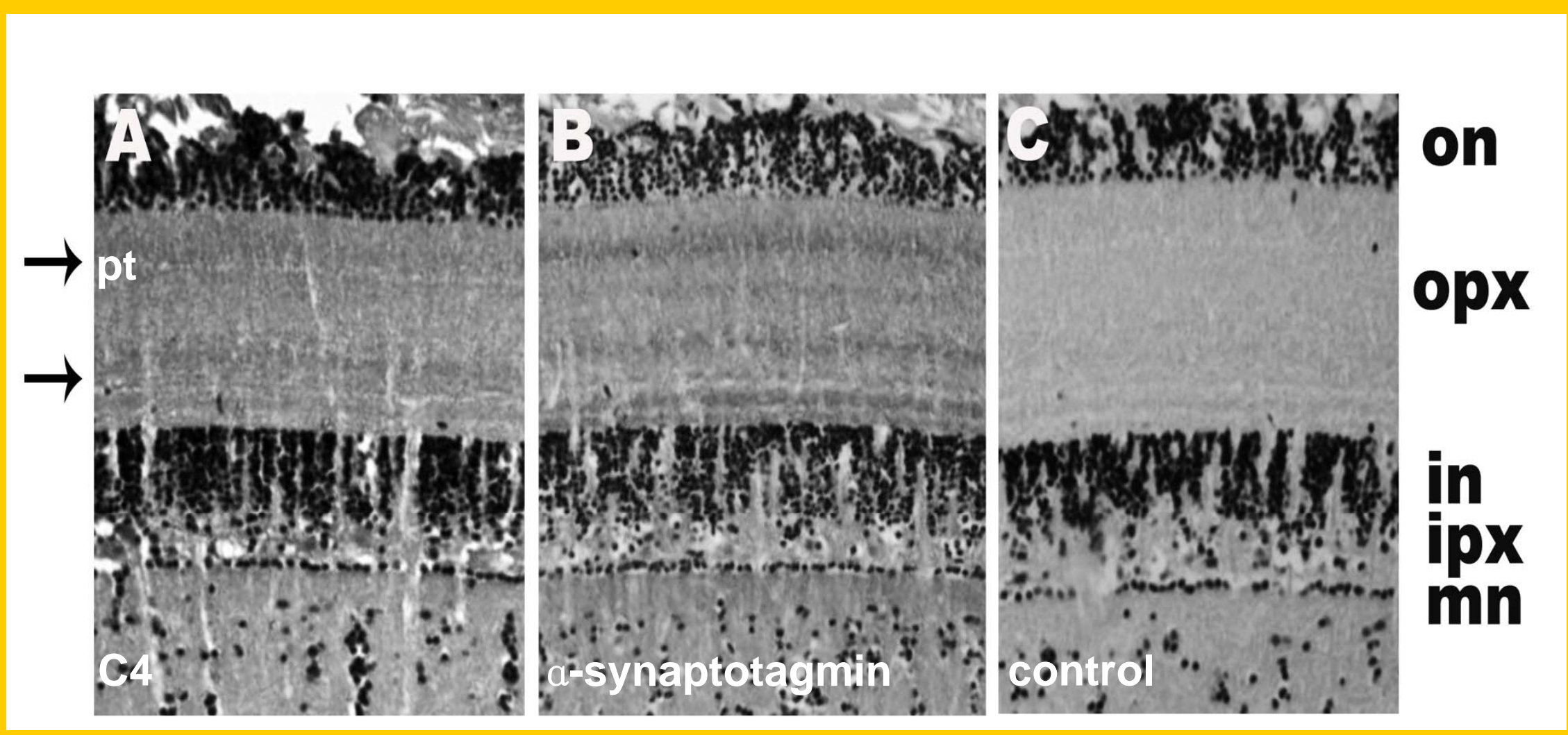

Figure 5

outer nuclear (on)

outer plexiform (opx)

inner nuclear (in)

inner plexiform (ipx)

mononuclear $(\mathrm{mn})$ layers 
C4 immunolabeling of squid optic lobe synaptosomes

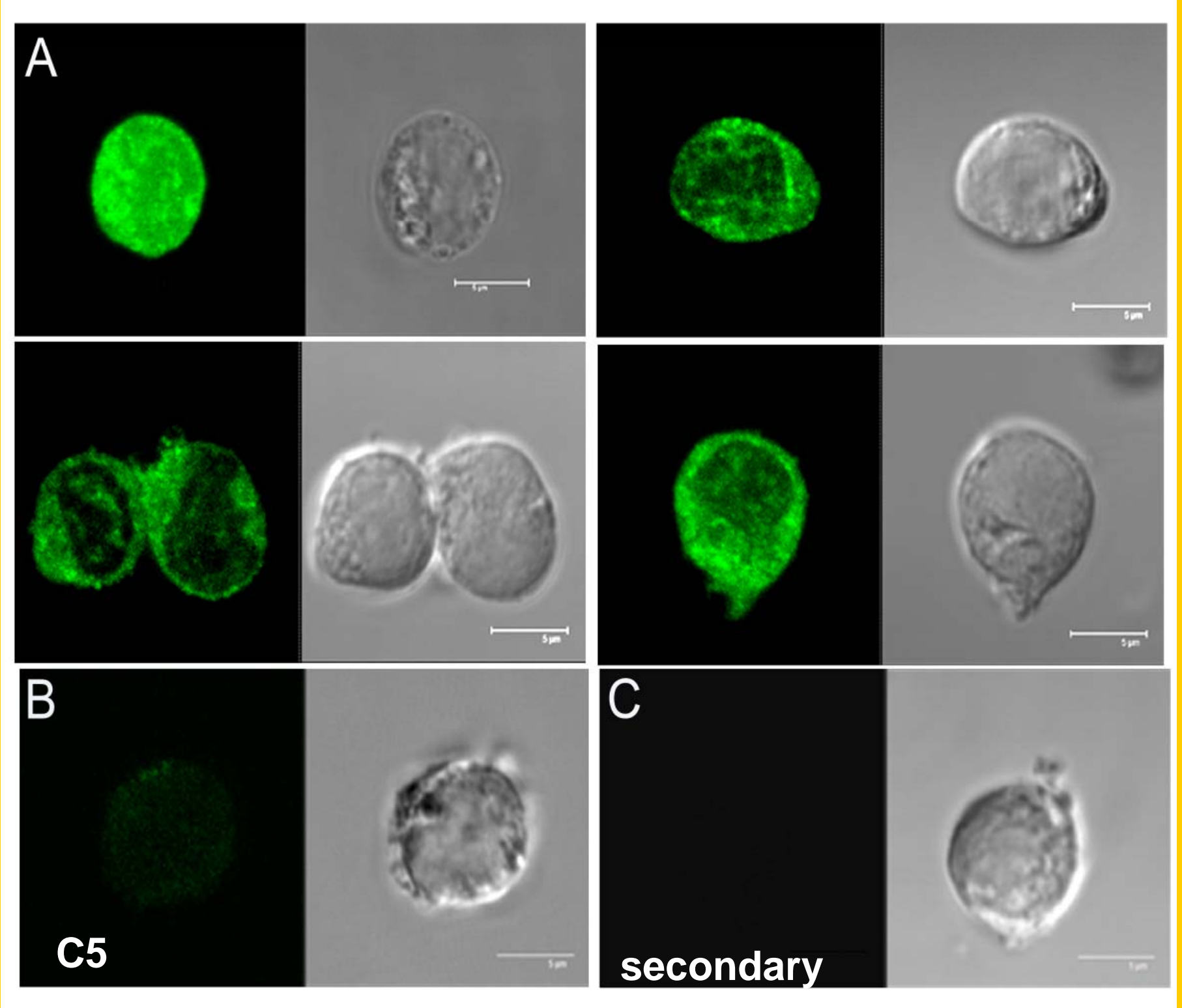

Figure 6 


\section{Synaptosomes from squid optic lobes}

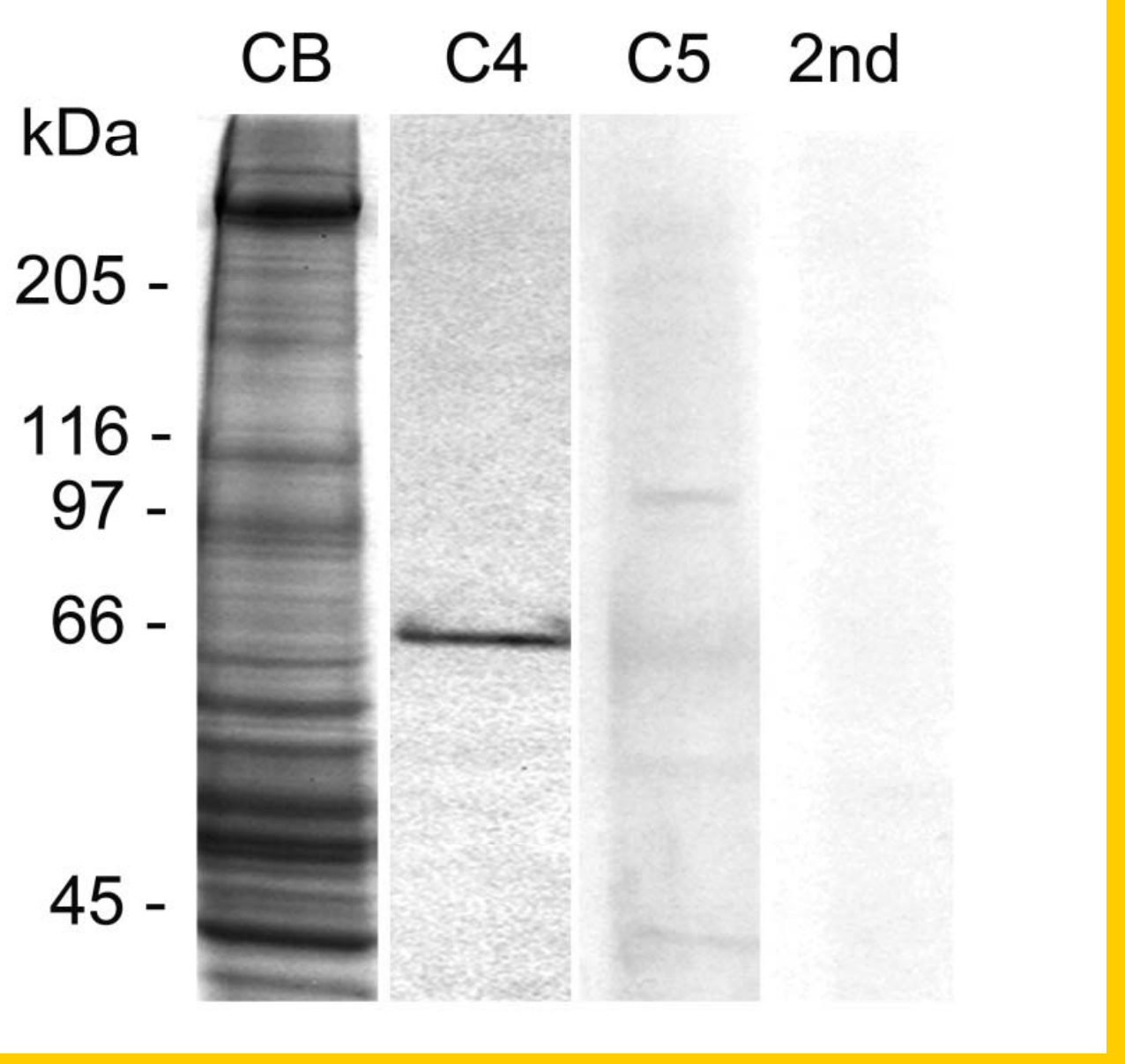

Figure 6D 


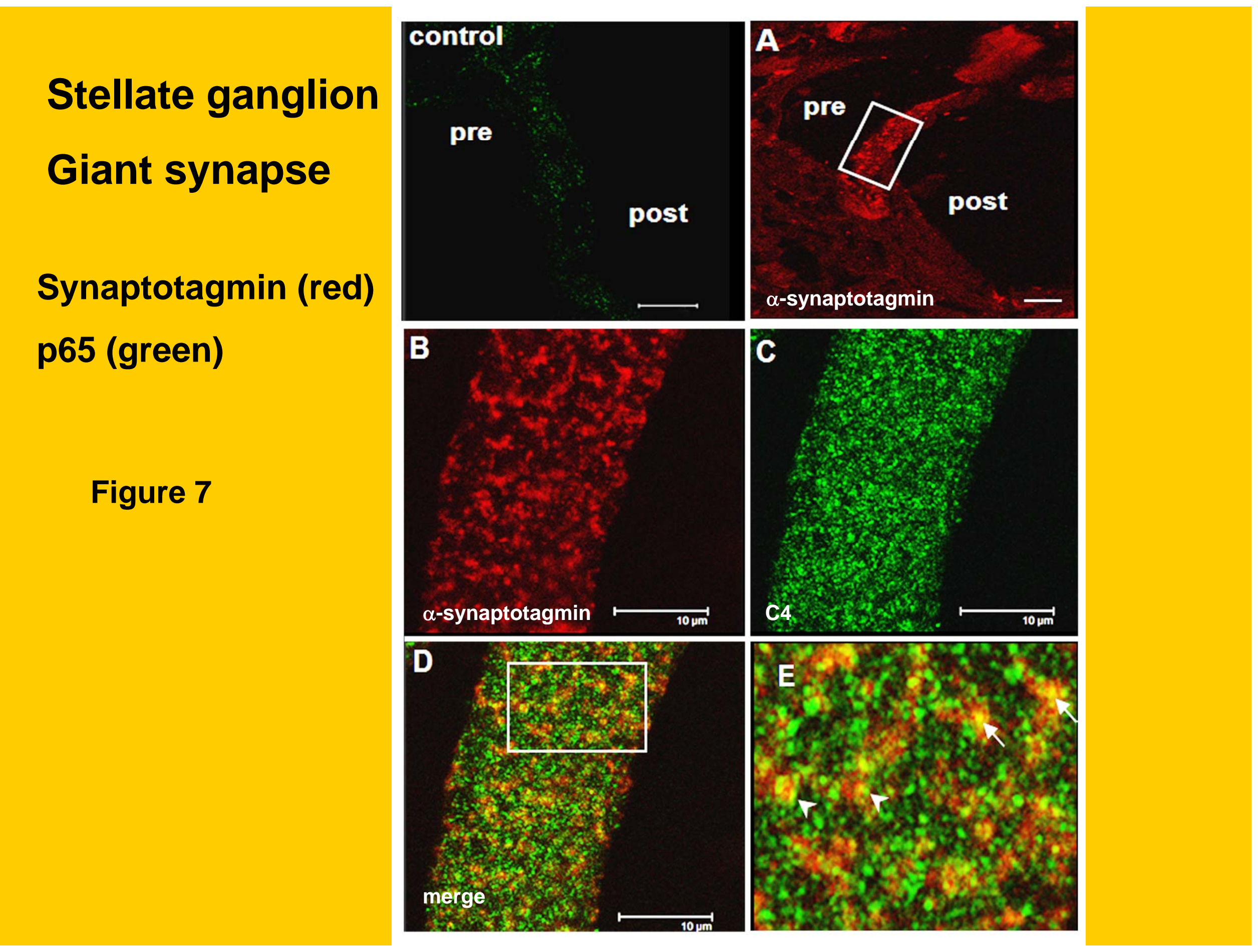

